JURNAL ILMIAH MANAJEMEN BISNIS DAN INOVASI

ISSN : 2356-3966 UNIVERSITAS SAM RATULANGI

Vol.6 No.3

\title{
PSAK 23 DAN PENERAPANNYA PADA PT JM (PERSERO) TBK.
}

Dias Adi Dharma, Achmad Fauzi , Kardinah Indriana Meutia, B.Wishman Siregar

Institut Bisnis \& Informatika Kosgoro 1957, Universitas Bhayangkara Jakarta Raya

A R T I C L E I N F O

Keywords: PSAK 23, Earning, SPM

Abstract : Revenue recognition, is a financial standard, specifically PSAK number 23. In PSAK number 23 it can be described and about revenue recognition. The collection method uses a qualitative research method with case studies. Implementation of operational, non-operational income, and implementation of the Company's financial statements. The Company's financial statements use the cash basis method as the basis for revenue recognition, which is only calculated based on cash receipts and disbursements. The Company applies Minimum Service Standards (SPM) in obtaining normal income.

Kata Kunci: PSAK 23, Penerapan Pendapatan, Standar Pelayanan Minimum
Abstrak: pengakuan pendapatan, adalah suatu standar keuangan, khususnya PSAK nomor 23. Pada PSAK nomor 23 dapat diuraikan dan tentang pengakuan pendapatan. Metode pengumpulan menggunakan metode penelitian Kualitatif dengan studi kasus. Penerapannya pendapatan Opersional, non Operasional, dan Penerapannya Laporan Keuangan Perusahaan. Laporan keuangan Perusahaan menggunakan metode cash basis sebagai dasar pengakuan pendapatan, dimana hanya diperhitungkan berdasarkan penerimaan dan pengeluaran kas.. Perusahaan menerapkan Standar Pelayanan Minimum (SPM) dalam mendapatkan pendapatan yang bersifat normal
Corresponding author:

Achmad Fauzy

achmad_fauzioke@yahoo.com 


\section{Latar Belakang}

\section{PENDAHULUAN}

PSAK adalah prosedur pembuatan laporan keuangan akuntansi berisi peraturan pencatatan, penyusunan, perlakuan, dan penyajian laporan keuangan.PSAK menetapkan dasar-dasar penyajian laporan keuangan yang bertujuan umum.

Suatu Pengakuan menjadi permasalahan dalam menentukan pendapatan. Pengakuan yang dimaskud merupakan saat dimana sebuah transaksi harus diakui sebagai pendapatan. Dalam permasalahan ini akan mucul sebuah transaksi yang berhubungan dengan pendapatan. Apabila Pendapatan diakui tidak sama dengan yang seharusnya berarti pendapatan salah ( apakah terlalu atau terlalu kecil ). Hal ini dapat berakibat informasi yang disajikan dalam laporan laba rugi tidak tepat dan dapat menyebabkan suatu kesalahan dalam pengambilan keputusan. Pada PSAK nomor 23 diuraikan dan dijelaskan tentang pengakuan pendapatan yang dapat digunakan bagi perusahaan JM

\section{Tujuan Penelitian}

Tujuan dari penelitian ini adalah :

1. Mengetahui penerapan PSAK ditinjau dari pendapatan operasional dan non operasional Perusahaan

2. Mengetahui sistem pencatatan pendapatan PT JM untuk mencapai laporan keuangan yang akuntabel.

3. Mengetahui pendapatan operasional yang bersifat normal.

\section{KAJIAN PUSTAKA}

\section{PSAK}

Suwardjono (2008:211 Dalam Standar akuntansi Laporan keuangan adalah dasar kerangka konseptual yang disusun oleh badan penyusun standar (atau yang berwenang) hal ini bertujuan untuk diberlakukan dalam bentuk dokumen resmi guna mencapai tujuan pelaporan keuangan negara.

Empat alasan standar akuntansi dibuat Belkoui (2006:161) :

1. Standar dapat memberikan informasi mengenai posisi keuangan, kinerja, dan penyelenggaraan perusahaan.

2. Standar keuangan dapat memberikan pedoman dan aturan tindakan bagi para akuntan publik

3. Standar keuangan dapat memberikan laporan database kepada pemerintah mengenai berbagai variabel yang dianggap sangat penting.

Standar ini dapat menumbuhkan minat dalam prinsip-prinsip kehati-hatian.

\section{Pengakuan Pendapatan PSAK No.23}

Pernyataan Standar Akuntansi Keuangan (PSAK) 23 paragraf 23 (Revisi ke 2012) diketahui bahwa pendapatan akan diakui bila kemungkinan manfaat ekonomi masa depan akan mengalir ke perusahaan. Pernyataan Standar Akuntansi Keuangan No. 23 paragraf ke 24 (Revisi 2012) menyatakan penjualan jasa diakui dengan persentase penyelesaian bila memenuhi kondisi sebagai berikut:

1. Jumlah pendapatan yang dapat dikur dengan andal.

2. Kemungkinan besar dari manfaat ekonomi dihubungkan dengan transaksi yang akan mengalir ke entitas.

3. Dari Tingkat penyelesaian suatu transaksi akhir periode pelaporan yang dapat diukur secara andal.

4. Biaya yang timbul dari transaksi dan biaya dalam menyelesaikan transaksi tersebut dapat diukur secara andal.

PSAK No.23 paragraf ke 23 (Revisi 2012) nilai wajar adalah Sejumlah asset yang pertukarkan atau liablitas yang diselesaikan diantara pihak-pihak yang berkeinginan. 


\section{Pendapatan}

Ikatan Akuntansi Indonesia (2010:23), "Pendapatan berasal dari aktivitas normal perusahaan selama satu periode.

Santoso (2010:26) , Pendapatan berasal dari peningkatan aktiva suatu perusahaan atau penyelesaian kewajiban perusahaan atau campuran keduanya. Samryn (2014:43) pendapatan dapat berasal dari "Aliran masuk aktiva atau pengurangan utang.

Dari pengertian diatas dapagt diketahui bahwa pendapatan sering disamakan arti dengan istilah penghasilan, tetapi sebenarnya adalah berbeda. Perbedaan dijelaskan sebagai berikut:

"Penghasilan didefinisikan sebagai bentuk peningkatan dari manfaat ekonomi selama periode akuntansi sedangkan Penghasilan meliputi pendapatan maupun keuntungan”.(IAI:2010:23)

\section{Jenis- Jenis Pendapatan}

Pendapatan dapat dibedakan menjadi dua bagian, Kusnadi (2000:19) yaitu:

a. Pendapatan operasional

Pendapatan Operasional merupakan pendapatan yang timbulkan dari proses terjadinya bisnis, Dapat diketahui bahwa pendapatan perusahaan bersifat normal sesuai dengan tujuan dan usaha perusahaan

Dapat diketahui bahwa Pendapatan yang diperoleh perusahaan dalam periode tertentu, akan tetapi bukan diperoleh dari kegiatan operasional perusahaan.

\section{Konsep Pendapatan}

Theodorus M.Tuanakotta (2000;153) menyatakan bahwa:

1. Pendekatan yang berpusat pada arus masuk perusahaan daripada assets yang ditimbulkan oleh kegiatan operasional.

2. Pusat perhatian pada pencapan barang dan jasa oleh perusahaan,dimana transfer dari barang dan jasa kepada konsumen atau produsen lain.

Disamping itu terdapat dua konsep yang sangat erat berhubungan dengan masalah proses pendapatan yaitu :

1. Pembentukan pendapatan (Earnings Process)

Proses pembentukan pendapatan adalah Konsep yang didasarkan atas proses terjadinya tahap kegitan produksi, pemasaran dan proses terjadinya pemasukan hingga piutang mempunyai peran penting dalam memberikan kontribusi dalam meningkatkan pendapatan.

2. Proses realisasi pendapatan (realization process)

Proses realisasi pendapatan adalah proses pendapatan yang berasal dari suatu proses produksi barang atau jasa , hasil akhir dari barang atau jasa yang dihasilkan dimanfaatkan dengan penjualan kepada konsumen , baik secara tunai atau secara kredit

\section{Pengakuan Pendapatan (Revenue Recognition)}

Pengakuan (recognition) dalah proses pembentukan pendapatan yang memenuhi standar akuntansi dalam laporan neraca dan laba rugi.

Harahap (2011:96) menyatakan: 
1. Ada kemungkinan manfaat ekonomi yang berkaitan dengan pos yang mengalir ke dalam perusahaan.

2. Pos mempunyai nilai atau biaya yang dapat diukur.

Pendapatan dan keuntungan diakui bila:

1. Pendapatan dan keuntungan telah direalisasi

2. Pendapatan dihasilkan

Kedua ktiteria itu dapat penuhi pada titik penjualan (point of sale), yang sering terjadi ketika barang diantara atau ketika pelayanan diberikan kepada pelanggan.

Belkoui (2013:569) menyatakan metode pengakuan pendapatan yaitu:

\section{Accrual Basis}

Teknik accrual basis dapat memiliki fitur pencatatan transaksi yang sudah dapat dicatat karena transaksi tersebut memiliki implikasi uang masuk atau keluar di masa depan.

\section{Cash Basis}

Metode cash basis, dapat diketahu dari pendapatan yang diakui ketika kas diterima sedangkan beban diakui saat kas dibayarkan,

\section{Penelitian Terdahulu}

Desi Eliza, Penerapan PSAK 23 PT Angkasa Pura II Bandar Udara Raja Haji Fisabilillah (RHF).bertujuan untuk mengetahui pengakuan, pengukuran dan pengungkapan pendapatan pada Bandar Udara Raja Haji Fisabilillah (RHF) Tanjungpinang telah sesuai secara keseluruhan dengan PSAK No. 23. Diketahui bahwa pengakuan, pengukuran menjadi masalah lain yang cukup rumit dalam penerapan akuntansi pendapatan. Pada PT (Persero) Angkasa Pura II Bandar Udara Raja Haji Fisabilillah Tanjungpinang, penghitungan pendapatan dihitung berdasarkan jasa yang diterima dikalikan dengan tarif yang berlaku.

Rina Dwirinawati Pengakuan Dan Pengukuran Pendapatan menurut PSAK No. 23 Pada Perusahaan Biro Jasa Perjalanan. Hasil dari penelitiannya diketahui apakah metode yang diterapkan oleh perusahaan dalam mengakui dan mengukur pendapatannya telah sesuai dengan PSAK Nomor23.Beberapa Aspek-aspek masalah yang diteliti oleh penulis mengenai catatan , transaksi, pengakuan pendapatandan besarnya pendapatan. Diketahui Hasil penelitian pada PT. Megananda Trans, pendapatan PT. Megananda Trans menggunakan metode dasar akrual dimana pendapatan diakui pada saat terjadinya transaksi, sebagaimana diketahui dalam Standar Akuntansi Keuangan sehingga laporan keuangan yang disajikan dapat diandalkan. Dalam pengukuran pendapatan PT.Megananda Trans telah menetapkan PSAK 23diketahui pula bahwa pada PT. Megananda Trans menggunakan metode cash basis, Pengukuran pendapatan yang diterapkan PT. Megananda Trans menggunakan nilai wajar sebagaiukuran dalam mengukur pendapatan yang diakui.

\section{Hipotesis Penelitian}

Penelitian inimenggunakan metode penelitian Kualitatif studi kasus , penelitian dilakukan secara mendalam dan pemeriksaan yang lebih menyeluruh. Dalam penelitian dengan studi kasus berusaha mendeskripsikan suatu latar, objek atau peristiwa berdasarkan pada fokus dan sub fokus penelitian. jika fokus penelitian berusaha menela'ah fenomena kontemporer (masa kini) dalam kehidupan nyata.

\section{Populasi dan Sampel}

Populasi yang digunakan pada penelitian ini adalah seluruh Laporan keuangan yang terkait dengan Perusahaan berdasarkan PSAK 23..

\section{Metode Analisis}

Beberapa tahapan yang harus dilakukan peneliti antara lain sebagai berikut : 1. membuat rancangan penelitian; 2. membuat instrumen penelitian; 3. mengumpulkan data; 4. mengolah dan menganalisis data; 5. membuat laporan.

\section{Ruang Lingkup Studi}

Lingkup kegiatan dari kajian penelitian meliputi:

\section{a). $\quad$ Lingkup Wilayah Studi}


Wilayah kegiatan penelitian adalah PT JM, Persero

b). Lingkup Obyek Studi

Lingkup Objek studi adalah Pendapatan Operasional, non Operasional dan Laporan Keuangan PT JM, Persero

c). $\quad$ Lingkup Kegiatan Studi

Lingkup kegiatan Penelitian Pendapatan Operasional, Non Operasional dan Laporan Keuangan PT JM ,

Persero yang terdiri dari ;

- Proses persiapan

Tahap persiapan pekerjaan, menyusun kelengkapan data ( berkas ) mobilisasi sumber daya pekerjaan (termasuk informan terkait), rencana kegiatan, jadwal pelaksanaan dan lain sebagainya, yang dikonsultasikan.

- Pengumpulan Data

Pengumpulan data dilakukan dengan mengumpulkan data primer, data sekunder, kunjungan lapangan untuk obsevarsi wilayah kajian serta studi-studi yang mendukung kajian studi ini.

\section{HASIL PENELITIAN DAN PEMBAHASAN}

\section{Data Penelitian Pendapatan Opersional, Non Operasional}

Laba Rugi Perusahaan

\begin{tabular}{|c|c|c|c|c|c|}
\hline \multicolumn{5}{|c|}{ LABA RUGI FORMAT PROGNOSA } & \\
\hline \multicolumn{5}{|c|}{ PERIODE DESEMBER } & \\
\hline \multicolumn{6}{|c|}{ CABANG CAWANG TOMANG CENGKARENG } \\
\hline \multirow{2}{*}{ Uraian } & Balance & Balance & Balance Budget & \multirow{2}{*}{ Varian } & \multirow{2}{*}{$\%$} \\
\hline & Tahun Lalu & Tahun ini & Tahun ini & & \\
\hline \multicolumn{6}{|l|}{$\begin{array}{l}\text { OPERASI YANG } \\
\text { DILANJUTKAN }\end{array}$} \\
\hline Pendapatan Tol & 1.062.247.719.065,00 & 1.109.956.632.081,00 & 1.087.509.066.565,00 & 22.447.565.516,00 & 2,06 \\
\hline $\begin{array}{l}\text { Pendapatan } \\
\text { Konstruksi }\end{array}$ & 47.324.795.407,55 & - & - & - & $\mathrm{n} / \mathrm{m}$ \\
\hline $\begin{array}{l}\text { Pendapatan Usaha } \\
\text { Lain }\end{array}$ & 27.079.092.330,57 & $32.706 .793 .158,16$ & 26.247.000.000,00 & $6.459 .793 .158,16$ & 24,61 \\
\hline $\begin{array}{l}\text { Jumlah Pendapatan } \\
\text { Usaha }\end{array}$ & $1.136 .651 .606 .803,12$ & $1.142 .663 .425 .239,16$ & $1.113 .756 .066 .565,00$ & 28.907.358.674,16 & 2,60 \\
\hline Beban Usaha & & & & & \\
\hline Beban SDM & $122.413 .587 .237,00$ & $139.834 .826 .829,00$ & $146.743 .757 .615,41$ & $6.908 .930 .786,41$ & 4,71 \\
\hline Pengumpulan Tol & $23.183 .537 .252,51$ & 29.093.638.631,72 & $27.135 .637 .425,00$ & $1.958 .001 .206,72$ & 7,22 \\
\hline
\end{tabular}




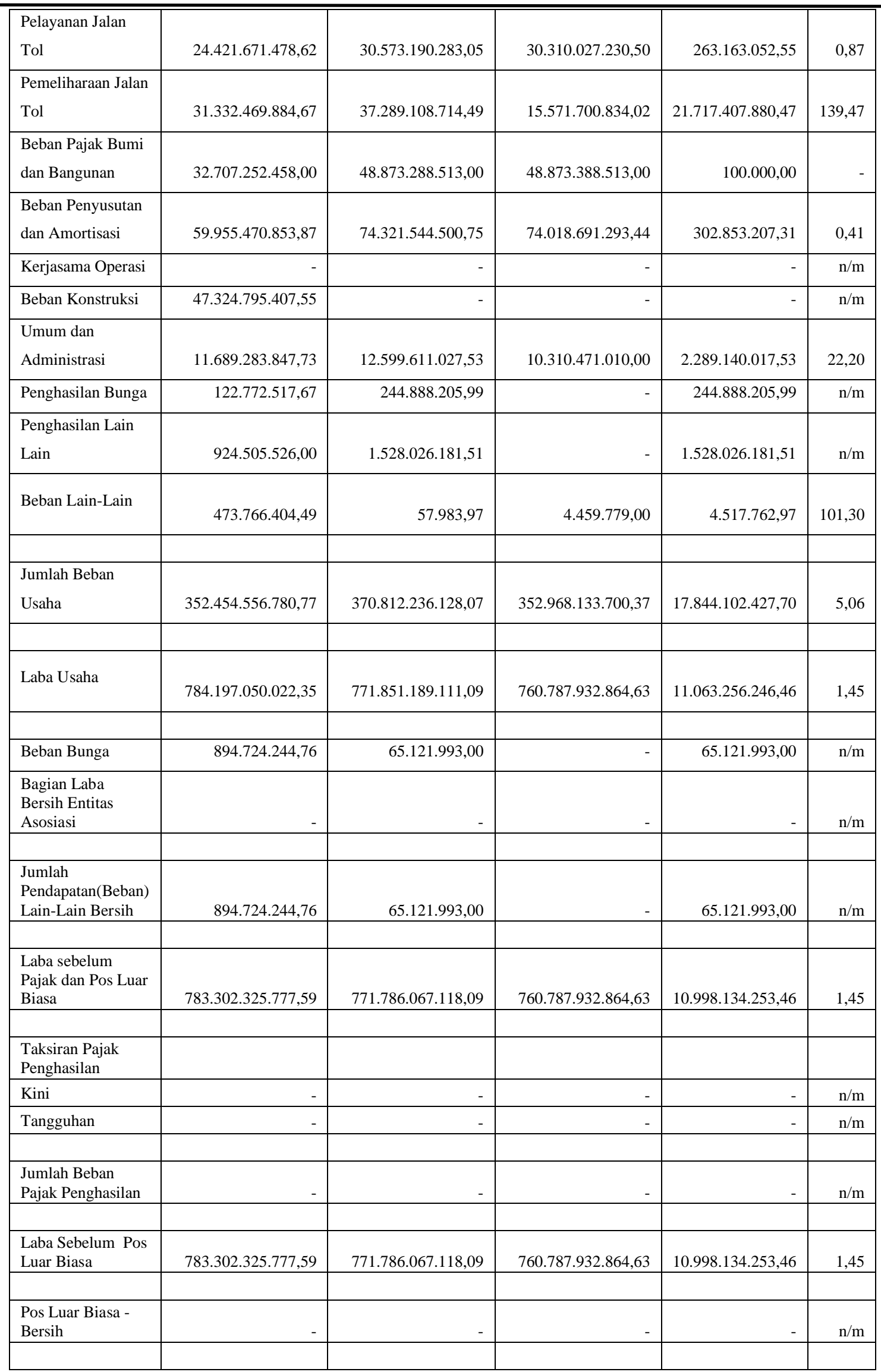




\begin{tabular}{|l|r|r|r|r|r|}
\hline $\begin{array}{l}\text { Laba Sebelum Hak } \\
\text { Minoritas }\end{array}$ & $783.302 .325 .777,59$ & $771.786 .067 .118,09$ & $760.787 .932 .864,63$ & $10.998 .134 .253,46$ & 1,45 \\
\hline & & & & & \\
\hline Hak Minoritas & & & & & \\
\hline & & & & & \\
\hline Laba Bersih & $783.302 .325 .777,59$ & $771.786 .067 .118,09$ & $760.787 .932 .864,63$ & $10.998 .134 .253,46$ & 1,45 \\
\hline
\end{tabular}

\section{Pembahasan}

\section{Hasil Penelitian PSAK}

Dari hasil penelitian dapat diketahui bahwa hasil pendapatan yang diterima oleh PT JM (Persero) Tbk yaitu pendapatan operasional dan non operasional berupa pendapatan tol dan lainnya. Dapat diketahui bahwa PT JM (Persero) Tbk Cabang Cawang Tomang Cengkareng mengakui pendapatan nya pada saat semua transaksi diterima langsung.

PT JM , Persero menggunakan metode cash basis sebagai dasar pengakuan pendapatan berdasarkan penerimaan dan pengeluaran kas, dengan penggunaan dasar tunai atau cash basis pendapatan dari penjualan barang atau jasa hanya dapat diperhitungkan pada saat tagihan langganan diterima.

Dari hasil penelitian diketahui bahwa PT JM (Persero) Tbk telah memenuhi standar sesuai dengan PSAK No.23 Tahun 2010, dan dapat dikatakan perusahaan telah mengakui pendapatan sebagiamana semestinya.

Dapat diketahu dari hasil penelitian rekapitulasi pendapatan operasional dan non operasional PT JM Cabang Cawang Tomang Cengkareng:

Pada proses pencatatan pengakuan pendapatan PT JM (Persero) Tbk dimuai dari hasil pendapatan tol ruas Cawang sampai pada bagian pengumpulan tol dan disetorkan ke bank, bukti setoran bank dan bukti transfer diterima langsung dari bank, transfer otomatis dilakukan setiap hari langsung dibukukan oleh bank, lalu di bagian manajemen pengumpulan tol rekonsiliasi data setoran bank dibuat invoice voucherpenerimaan saat itulah pendapatan baru diakui, dan diinput data ke laporan laba rugi komprehensif lalu diproses menjadi laporan neraca mutasi bulanan.

Contoh dari penerapan cash basis yang dilakukan oleh kantor pusat yaitu sebagai berikut, selama bulan januari 2014 perusahaan mendapatkan total penghasilan dari pendapatan operasional dan non operasional sebesar 94.816.404.703 dan dikurangi pajak penghasilan yaitu $24 \%$ pertahun.

Dengan demikian jurnal yang dibuat sehubungan dengan total pendapatan operasional dan non operasional adalah sebagai berikut :

Perhitungan pendapatan bersih yang diterima oleh PT JM (Persero) Tbk Cabang Cawang Tomang Cengkareng :

- Pajak 24\% / $12=2 \%$ perbulan

- Total Pendapatan sebesar

94.785.065.976

- $2 \%$ x 94.785.065.976

$(1.895 .701 .319,52)$

Pendapatan bersih yang di terima

$92.889 .364 .656,5$

Jurnal :

- Untuk mencatat pengakuan pendapatan saat input invoice di kantor pusat :
31 Jan 2014
Bank
94.785.065.976
Pendapatan Tol
92.889.364.656,5
Hutang Pajak
$1.895 .701 .319,52$

- Untuk mencatat pengakuan pendapatan di kantor cabang :
31 Jan 2014
Bank
94.785.065.976 


\section{Pendapatan Bersifat Normal}

Pendapatan Tol 94.785.065.976

Perusahaan dapat mengetahui seberapa besar penghasilan yang diterima dari dari pendapatan selain itu dapat diketahui bahwa setiap pendapatan PT JM juga dapat diukur dari jumlah kendaraan yang masuk ruas cawang sampai dengan ruas pluit, dan penyewaan lahan untuk rest area dan sewa lahan untuk iklan dengan asumsi harga tiket tol dan penyewaan lahan tersebut sudah ditentukan oleh perusahaan dan diakui setiap transaksinya.

\section{PENUTUP}

\section{Kesimpulan}

Berdasarkan hasil penelitian ini, dapat diketahui mengenai Penerapan PSAK 23 ( Pendapatan Operasional, Non Operasional ) dan Keterkaitan Dengan Laporan Keuangan Perusahaan dapat diambil kesimpulan:

1. Penerapan pengakuan pendapatan yang digunakan oleh PT JM (Persero) Tbk Cabang Cawang Cengkareng telah sesuai dengan PSAK No.23 Tahun 2010, diketahu dari pendapatan perusahaan yang diakui pada saat direalisasi dan dihasilkan.

2. PT JM melakukan kegiatan proses pencatatan pendapatan dimulai dari pendapatan tol ruas cawang sampai dengan pluit, diketahui juga bahwa PT JM menerapkan Standar Operasional Perusahaan (SOP) untuk mengeluarkan biaya yang diperlukan selama kegiatan tersebut berlangsung.

3. PT JM menerapkan Standar Pelayanan Minimum (SPM) dalam mendapatkan pendapatan yang bersifat normal dan kegiatan yang dilakukan oleh perusahaan dapat berjalan dengan baik.

Saran

Bedasarkan hasik kesimpulan diatas saran dapat diberikan bagi Perusahaan, yaitu sebagai berikut:

1. Dalam perlakuan akuntansi pendapatan dengan PSAK No.23 harus dipertahankan dengan cara memperhatikan prosedur yang ada.

2. Perusahan dapat Standar Operasional Perusahaan dengan cara memperhatikan biaya apa saja yang diperlukan selama kegiatan berlangsung

3. Perusahan dapat meningkatkan Standar Pelayanan Minimum terhadap kegiatan yang dilakukan dengan cara menerapkan standar kekesatan jalan, standar 6 detik, dan lain lain. Dengan menerapkan SPM ini diharapkan pendapatan dapat mengalami peningkatan yang lebih siginifikan.

\section{DAFTAR PUSTAKA}

Belkoui, Ahmed Riahi. (2006). Teori Akuntansi Edisi Kelima. Jakarta: Salemba Empat.

Belkoui, Ahmed Riahi. (2013). Accounting TheoryBuku 1 Edisi 15. Jakarta:Salemba Empat

Harahap, Sofyan Syafri. (2011). Teori Akuntansi. Jakarta:Raja Grafindo.

Ikatan Akuntansi Indonesia. (2010). Standar Akuntansi Keuangan (PSAK) No.23

Ikatan Akuntansi Indonesia. (2012). Standar Akuntansi Keuangan. Jakarta:Salemba Empat.

Kusnadi. (2000). Akuntansi Keuangan Menengah (Intermidate) . Malang: Universitas Brawijaya. 
Miles \& Huberman, Analisis Data Kualitatif,, 2007, Buku Sumber tentang Metode-Metode Baru. Terjemahan Tjetjep Rohendi Rohisi. Jakarta: Universitas Indonesia

Prasetya, I. (1999). Logika dan Prosedur Penelitian : Pengantar Teori dan Panduan Praktis Penelitian Sosial bagi Mahasiswa dan Peneliti Pemula,Jakarta : STAIN

Purba, D. E. (2018). Penerapan PSAK 23 Tentang Akuntansi Pendapatan Studi Pada PT Angkasa Pura II Bandar Udara Raja Haji Fisabilillah (RHF). Jurnal Ekonomi Bisnis Volume 5, no.2, Januari

Rina D. (2017). Pengakuan dan Pengukuran Pendapatan Menurut PSAK Pada Perusahaan Biro Jasa Perjalanan. Jurnal Ilmu dan Riset Akuntansi, Volume 6, no.1, Januari 2017

Santoso, I. (2010). Akuntansi Keuangan Menengah (Intermidate Accounting). Bandung:Buku Satu Refika Aditama

Samryn, L.M. (2014). Pengantar Akuntansi Cetakan Ketiga. Jakarta: Rajawali Pers.

Sukardi (2005). Metode Penelitian Pendidikan : Kompetensi dan Prakteknya, Jakarta : Bumi Aksara

Suwardjono. (2008). Teori Akuntansi Perekayasa Pelaporan Keuangan. Yogyakarta: BPFE.

Tunakotta, T. (2000). Teori Akuntansi. Jakarta: Fakultas Ekonomi Universitas Indonesia. 